\title{
Development of Spectrophotometric methods for Assay of Salbutamol in Pharmaceutical Formulations
}

\author{
Theia'a N. Al-Sabha \\ Dept. of Chemistry/College of Education/Mosul University
}

Received

$11 / 9 / 2006$
Accepted

$2006 / 10 / 3$

\section{الخلصة}

وصفت طريقتان طيفيتان تميزتا بالحسلسية لقنير اللسالبيوتلمول بشكله الق ي وذ ي

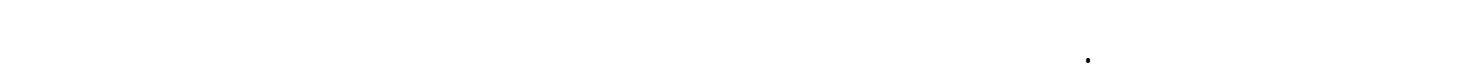

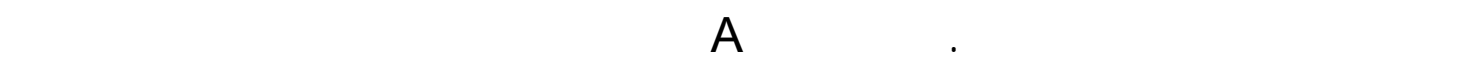
الكلثف 10,1 - فينانثرولين وقيس معقد الفيلووين الملون عند الطول ألموجي

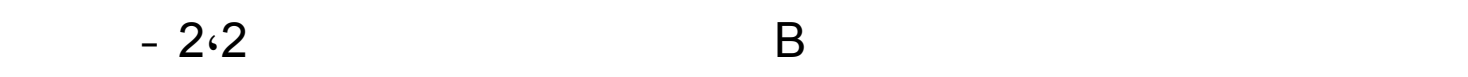

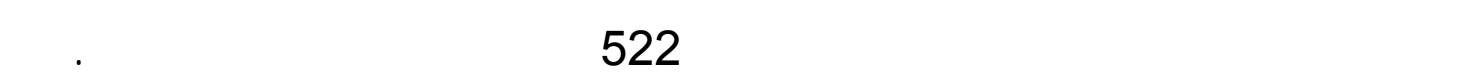

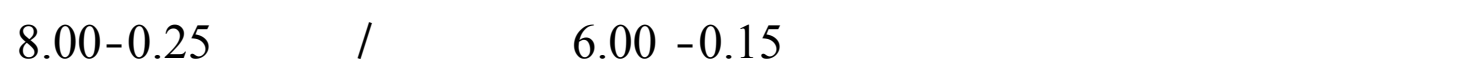

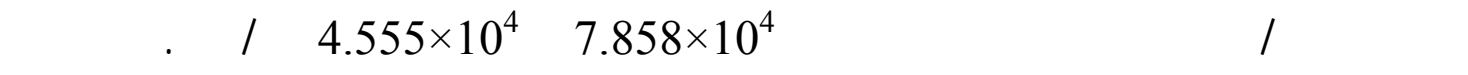

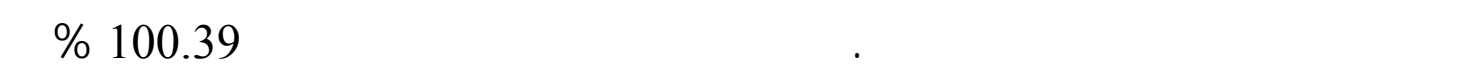

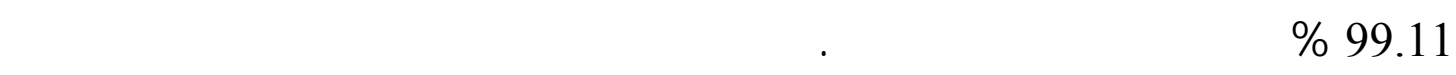

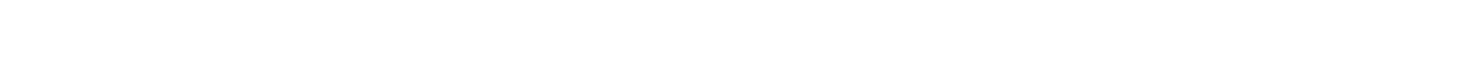
مقارينتها بنجاح مع الطريقة القيلسية المعتمة في الهستور البريطاني ومعطررائق لخرى.

\section{Abstract}

Two sensitive spectrophotometric methods are proposed for the determination of salbutamol in pure form and pharmaceutical preparations. The methods are based on the oxidation of salbutamol drug with $\mathrm{Fe}(\mathrm{III})$ in acidic medium. The liberated Fe(II) reacts with 1,10phenanthroline in method A and the ferroin complex is colorimetrically measured at $510 \mathrm{~nm}$ against reagent blank. Method B is based on the reaction of the liberated $\mathrm{Fe}$ (II) with 2,2'-bipyridyl to form a stable coloured complex with maximum absorption at $520 \mathrm{~nm}$ against reagent blank. Beer's law was obeyed in the concentration range of $0.15-6.00$ $\mu \mathrm{g} / \mathrm{ml}$ and $0.25-8.00 \mu \mathrm{g} / \mathrm{ml}$ with molar absorptivity of $7.858 \times 10^{4}$ and 
$4.555 \times 10^{4} 1 . \mathrm{mol}^{-1} . \mathrm{cm}^{-1}$ for method $\mathrm{A}$ and $\mathrm{B}$ respectively. The mean percent recoveries are $100.39 \%$ and $99.11 \%$ for both methods respectively. The suggested procedures could be used for the determination of salbutamol in pure and dosage forms without interference from common excipients. The proposed methods are successfully compared with the official and other spectrophotometric methods.

\section{Introduction}

Salbutamol \{(RS)-2-(1,1-dimethyl)ethylamino-1-[4-hydroxy-3(hydroxymethyl)-phenyl]ethanol $\}$ (I) is a direct-acting sympathomimethic with beta-adrenergic activity, employed as bronchodilator for the treatment of asthma and chronic obstructive pulmonary disease. It is also used to arrest premature labor in pregnancy [1]. This drug is usually administered alone, and only few forms contain salbutamol associated with a second active ingredient.

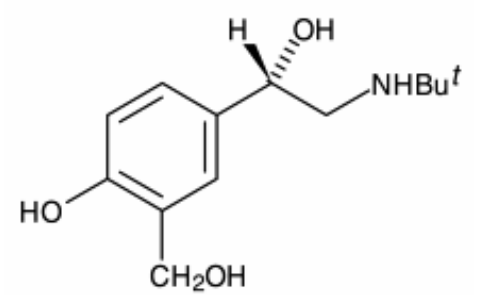

(I)

Several analytical techniques have been reported for the determination of salbutamol in its pharmaceutical preparations including chromatographic [2-4], fluorescent [5], electrochemical [6,7], a.c.oscillopolarographic titration[8] and flow injection [9] methods. The British Pharmacopoeia[10] involves two different methods for the analysis of pure drug of salbutamol and its formulations. The pure drug is analyzed by nonaqueous titration with perchloric acid while the analysis of tablets is carried out by liquid chromatography. HPLC is also the method of choice in the albuterol monograph in the United States Pharmaceopeia [11]. Spectrophotometry is the technique of choice even today due to its inherent simplicity. The most widely used technique for the assay of salbutamol in pharmaceuticals has been visible Spectrophotometry. The procedures based on different reactions such as redox [12, 13], oxidative coupling [14, 15], diazotization and coupling [16, 17], bromination [18], nitrosation [19], nitration [20], nitration followed by Meisenheimer complex formation [21], and charge-transfer complex formation [22] are found in literature. However, some of these procedures suffer from one or the other 
disadvantage such as poor sensitivity, extraction step, critical working conditions, or the use of organic solvents; and hence are unsatisfactory for routine analysis.

This paper describes two assay methods for salbutamol in pure and pharmaceutical formulations. The methods are based on the oxidation of salbutamol with ferric salt in acidic medium and subsequent complexation of ferrous ion produced with 1,10-phenanthroline reagent in the first method and with 2,2'-bipyridyl reagent in the second method.

\section{Experimental}

\section{Apparatus}

All absorption measurements were made on a Shimadzu UV-210A double - beam spectrophotometer supplied with a digital printer DP80Z and matched 1-cm optical silica cells.

\section{Reagents}

All reagents used were of analytical grade and obtained from Fluka and BDH companies.

$\mathrm{Fe}(\mathrm{III})$ solution $(0.03 \mathrm{M})$ was prepared by mixing $1.212 \mathrm{~g}$ of $\mathrm{Fe}\left(\mathrm{NO}_{3}\right)_{3} .9 \mathrm{H}_{2} \mathrm{O}$ with $5 \mathrm{ml}$ distilled water and $5 \mathrm{ml}$ of $0.05 \mathrm{M} \mathrm{HNO}_{3}$ and diluted to $100 \mathrm{ml}$ in a volumetric flask with distilled water. $0.9 \mathrm{~g}$ of

1,10-Phenanthroline solution (0.05M) was prepared by dissolving 1,10-phenanthroline in ethanol and diluted to the mark in a $100 \mathrm{ml}-$ volumetric flask with ethanol.

2,2'-Bipyridyl solution(0.05M) was prepared by mixing $0.2809 \mathrm{~g}$ of $2,2^{\prime}$-bypyridyl with minimum volume of ethanol and diluted to the mark in a $100 \mathrm{~m} 1$-volumetric flask with distilled water.

Standard solution of salbutamol(100ppm) was prepared by dissolving $0.01 \mathrm{~g}$ of pure salbutamol, provided from Sammara drug industries(SDI), in distilled water and diluted to the mark in $100 \mathrm{ml}-$ volumetric flask with distilled water and stored in amber coloured bottle in refrigerator. The solution were diluted as needed.

\section{General procedure}

Aliquots of standard drug solution of salbutamol were transferred into a series of $10 \mathrm{ml}$ calibrated flasks. To each of these were added $0.5 \mathrm{ml}$ of $\mathrm{Fe}\left(\mathrm{NO}_{3}\right)_{3} \cdot 9 \mathrm{H}_{2} \mathrm{O}$ solution and $2 \mathrm{ml}$ of 1,10-phenanthroline solution in method $\mathrm{A}$ and $0.3 \mathrm{ml}$ of $\mathrm{Fe}\left(\mathrm{NO}_{3}\right)_{3} \cdot 9 \mathrm{H}_{2} \mathrm{O}$ and $1.5 \mathrm{ml}$ of 2,2'-bipyridyl solution in method $\mathrm{B}$. The solutions were heated on a water bath adjusted at $90^{\circ} \mathrm{C}$ for $30 \mathrm{~min}$ in method $\mathrm{A}$ and at $70^{\circ} \mathrm{C}$ for $50 \mathrm{~min}$ in method $\mathrm{B}$. The solutions were cooled, diluted up to the mark with distilled water and 
mixed well. The absorbances of complexes were measured at $510 \mathrm{~nm}$ and at $522 \mathrm{~nm}$ in method A and B respectively against corresponding reagent blank. Calibration graphs were plotted.

\section{Analysis of dosage forms}

\section{Tablets}

Weighed and finely powdered 10 tablets (each containing $2 \mathrm{mg}$ salbutamol). An amount of powder equivalent to one tablet was weighed accurately and transferred into a $50 \mathrm{ml}$ beaker. The powder was completely dissolved in distilled water and the solution was filtered through a Whatmann 41 filter paper. The filtrate was made up to $50 \mathrm{ml}$ with distilled water in a calibrated flask to obtain $40 \mu \mathrm{g} / \mathrm{ml}$ salbutamol in a final dilution. An a liquid of drug solution was analysed as described in general procedure.

\section{Syrup}

Accurately $5 \mathrm{ml}$ of syrup sample was measured which is equivalent to $2 \mathrm{mg}$ of salbutamol was transferred into a $50 \mathrm{ml}$ calibrated flask and diluted to the mark with distilled water. An a liquid of drug solution was analysed as described in general procedure.

\section{Results and discussion}

The reaction involves the oxidation of salbutamol with FeIII salt and the librated FeII was reacted with 1,10-phenanthroline in method A and with 2,2'bipyridyl in method B.

\section{Absorption spectra}

Ferric salts play a prominent role in the spectrophotometric determination of many pharmaceutical drugs[23-25], acting as an oxidant, a ferric salt gets reduced to ferrous salt amount corresponds to drug concentration. The amount of $\mathrm{Fe}$ (II) can be determined using 1,10-phenanthroline and 2,2'-bipyridyl. However, method A and B are based on the oxidation of salbutamol drug with $\mathrm{Fe}(\mathrm{III})$ in acidic medium and produce $\mathrm{Fe}(\mathrm{II})$. The $\mathrm{Fe}(\mathrm{II})$ reacts with 1,10phenanthroline to produce a red coloured complex of tris-1,10-phenanthrolineiron(II) chelate (ferroin) $\left[\mathrm{Fe}(\mathrm{phen})_{3}\right]^{2+}$, as shown in scheme1, having the absorption maximum at $510 \mathrm{~nm}$ in method $\mathrm{A}$, and reacts with 2,2'-bipyridyl to produce a red coloured complex of tris-2,2'-bipyridyl-iron(II) chelate $\left[\mathrm{Fe}(\text { bipy })_{3}\right]^{2+}$, having absorption maximum at $522 \mathrm{~nm}$ in method $\mathrm{B}$, as shown in Fig.1. 
<smiles>CC(C)(C)NCC=C1C=CC(=O)C(CO)=C1</smiles>
Fe II $+3(1,10-$ Phenanthroline $\left.) \longrightarrow[\text { FeII-(1,10-Phen })_{3}\right]^{2+}$ Red complex
FeII $+3\left(2,2^{\prime}\right.$-bipyridyl $) \longrightarrow\left[\text { FeII }-\left(2,2^{\prime} \text {-bipyridyl }\right)_{3}\right]^{2+}$ Red complex

Scheme 1. Proposed reaction mechanism for assay of salbutamol

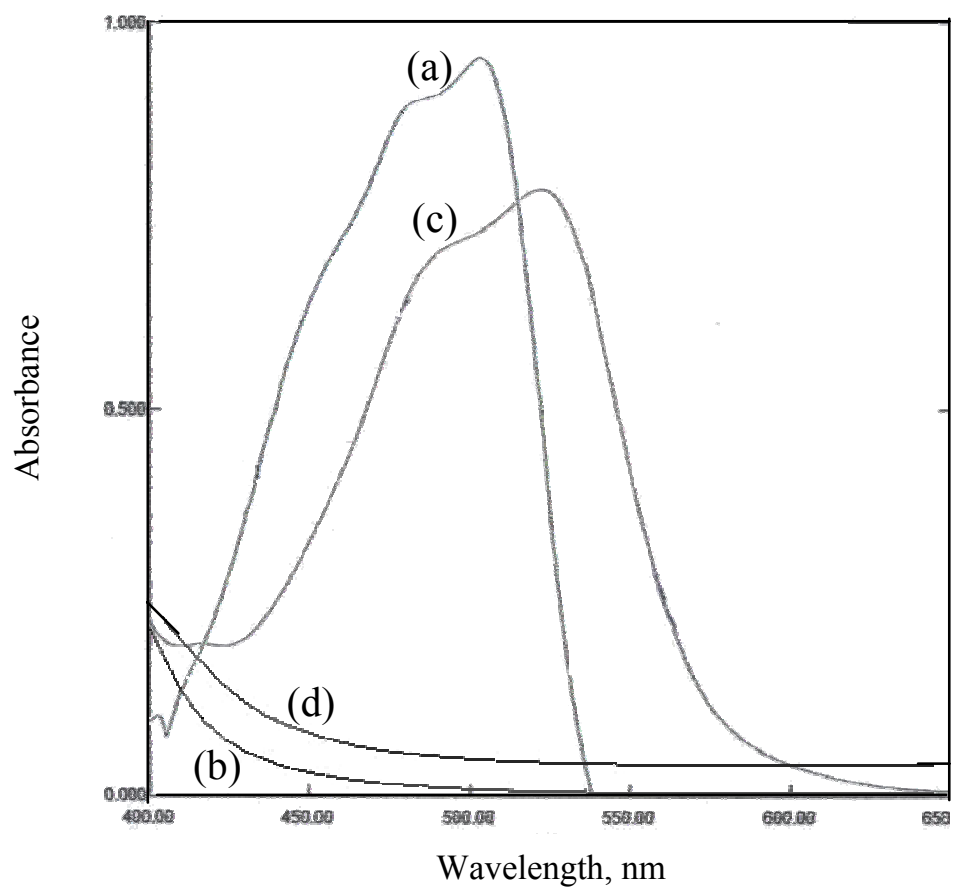

Fig.1. Absorption spectra of (a) salbutamol $(3 \mu \mathrm{g} / \mathrm{ml})-\mathrm{Fe}\left(\mathrm{NO}_{3}\right)_{3} \cdot 9 \mathrm{H}_{2} \mathrm{O}-$ 1,10-phenanthroline system and its reagent blank (b), (c) salbutamol $(4 \mu \mathrm{g} / \mathrm{ml})-\mathrm{Fe}\left(\mathrm{NO}_{3}\right) \cdot 9 \mathrm{H}_{2} \mathrm{O}-2,2^{\prime}$-bipyridyl system and its reagent blank(d) in a total volume of $10 \mathrm{ml}$.

\section{Optimization of reaction conditions}

The optimum reaction conditions for quantitative determination of salbutamol were established by varying one parameter at a time and keeping the others constants. 


\section{Effect of temperature and reaction time}

The reaction time was determined by following the colour development at room temperature and in a thermostatically controlled water-bath at different temperatures for both methods $\mathrm{A}$ and $\mathrm{B}$. The absorbance was measured at 5 min intervals against reagent blank treated similarly. The formation of coloured complexes were slow at room temperature and required longer time for completion. Hence efforts were made to accelerate the reaction by carrying out the reaction at higher temperatures. It was observed that the maximum absorbances were obtained when heating the reaction mixture at $90^{\circ} \mathrm{C}$ for $30 \mathrm{~min}$ in method $\mathrm{A}$ and at $70^{\circ} \mathrm{C}$ for $50 \mathrm{~min}$ in method B, (Fig.2). The stability of complexes was found constant after cooling to room temperature more than $24 \mathrm{~h}$.

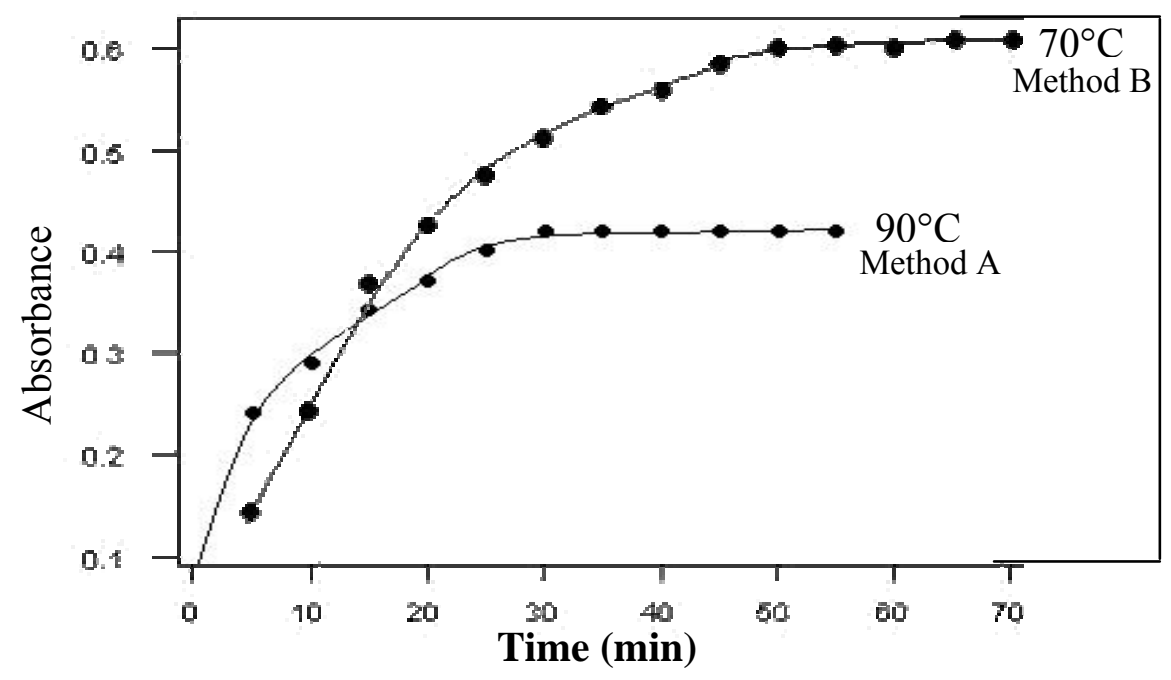

Fig.2. Effect of the time and temperature on the absorbance of $2.5 \mu \mathrm{g} / \mathrm{ml}$ salbutamol in method $\mathrm{A}$ and $5 \mu \mathrm{g} / \mathrm{ml}$ in method B.

\section{Effect of $\mathrm{Fe}\left(\mathrm{NO}_{3}\right)_{3} .9 \mathrm{H}_{2} \mathrm{O}$ concentration}

The effect of $1 \mathrm{ml}$ of different concentrations of ferric nitrate solution while keeping a fixed concentration of salbutamol and 1,10phenanthroline or 2,2'-bipyridyl on the absorbance of complex in both methods $\mathrm{A}$ and $\mathrm{B}$ were investigated. It was found that $0.03 \mathrm{M}$ concentration of ferric nitrate gave maximum absorbance for both methods. Also; the amount of this concentration was studied and found that the absorbance increased and reached maximum by using 0.5 and 0.3 $\mathrm{ml}$ of ferric nitrate in method $\mathrm{A}$ and $\mathrm{B}$ respectively, thus adopted as being optimal. 


\section{Effect of 1,10- phenanthroline and 2,2'- bipyridyl reagents concentration}

The effect of 1,10-phenanthroline and 2,2'-bipyridyl concentrations on the absorbance of the complex in method $\mathrm{A}$ and $\mathrm{B}$ respectively were investigated. It was found that $2 \mathrm{ml}$ and $1.5 \mathrm{ml}$ of $0.05 \mathrm{M}$ of $1,10-$ phenanthroline and 2,2'-bipyridyl respectively gave maximum absorbances which were used in subsequent experiments. Above these concentrations the absorbances were decreased as shown in Fig.3.

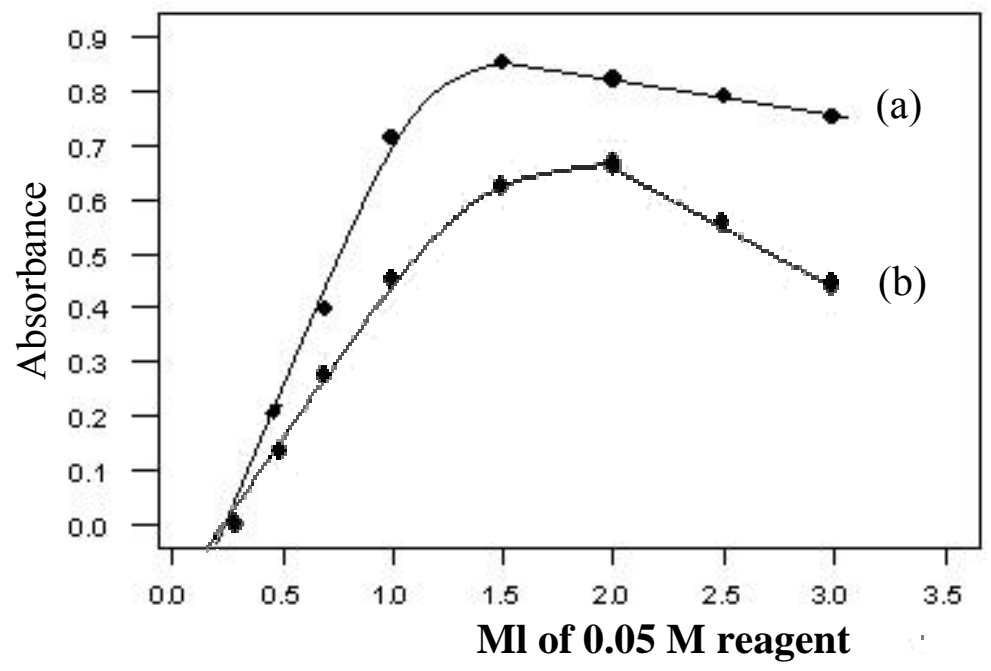

Fig.3. Effect of reagent concentration of

(a) $2,2^{\prime}$-bipyridyl in the presence of $5 \mu \mathrm{g} / \mathrm{ml}$ salbutamol and

(b) 1,10-phenanthroline in the presence of $2 \mu \mathrm{g} / \mathrm{ml}$ salbutamol

\section{Effect of order of addition}

To obtain optimum results the order of addition of reagents should be followed as given under the general procedure, otherwise a loss in colour intensity was observed.

However; the optimum reaction conditions for developing the colour intensity of the complex in method A and B are summarized in Table 1.

Table1. Optimum reaction conditions of salbutamol determination by the proposed methods.

\begin{tabular}{|c|c|c|c|c|c|}
\hline Method & $\begin{array}{c}\lambda_{\max } \\
(\mathrm{nm} \\
)\end{array}$ & $\begin{array}{c}\text { Temp } \\
\left({ }^{\circ} \mathrm{C}\right)\end{array}$ & $\begin{array}{c}\text { Developme } \\
\text { nt time } \\
(\mathrm{min})\end{array}$ & $\begin{array}{c}\text { Stabilit } \\
\mathrm{y} \\
\text { period* } \\
(\mathrm{h})\end{array}$ & $\begin{array}{c}\text { Reagent } \\
0.05 \mathrm{M} \\
(\mathrm{ml})\end{array}$ \\
\hline $\mathrm{A}$ & 510 & 90 & 30 & $>24$ & 2.0 \\
\hline $\mathrm{B}$ & 522 & 70 & 50 & $>24$ & 1.5 \\
\hline
\end{tabular}

* After cooling to room temperature 


\section{Quantification}

In order to investigate the range in which the coloured complexes adhere to Beer's law, the absorbances of the complexes were measured at their respective $\lambda_{\max }$ values after developing the colour by following the suggested procedures for a series of solutions containing increasing amounts of salbutamol drug. The Beer's law limits, molar absorptivity and Sandell's sensitivity values were evaluated and are given in Table 2, which are indicated that the two methods are sensitive. The linearity was represented by the regression equation and the corresponding correlation coefficients for the salbutamol determined by the proposed methods represents excellent linearity (Fig.4). The relative standard deviation (RSD) and accuracy (average recovery $\%$ ) for the analysis of six replicates of each three different concentrations of salbutamol $(1,3$ and $5 \mu \mathrm{g} / \mathrm{ml})$ indicated that both methods are precise and accurate.

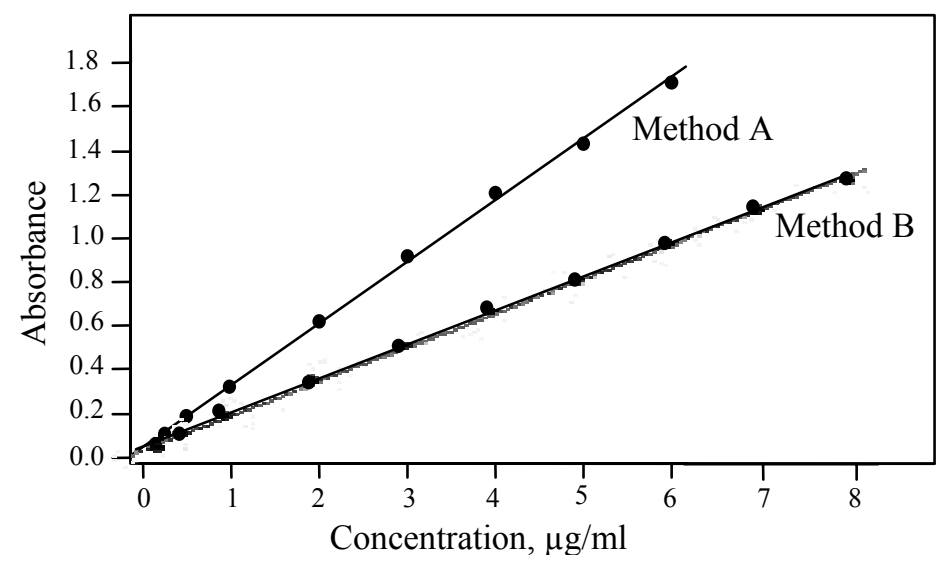

Fig.4 Calibration graphs for the determination of salbutamol

Table 2. Summary of optical characteristics and statistical data for the proposed methods

\begin{tabular}{lcc}
\hline \multirow{2}{*}{ Parameter } & \multicolumn{2}{c}{ Values of } \\
\cline { 2 - 3 } & \multicolumn{1}{c}{ Method A } & Method B \\
\hline Beer's law limits $\left(\mu \mathrm{g} / \mathrm{ml}^{\prime}\right)$ & $0.15-6.00$ & $0.25-8.00$ \\
Molar absorptivity $\left(1 . \mathrm{Mol}^{-1} \mathrm{~cm}^{-1} \times 10^{4}\right.$ & 7.8580 & 4.5550 \\
Sandell's sensitivity $\left(\mathrm{ng} \mathrm{cm}^{-2}\right)$ & 5.28 & 11.86 \\
Correlation coefficient & 0.9992 & 0.9987 \\
Regression equation $(Y)^{*}$ & & \\
Slope, $a$ & 0.3283 & 0.1903 \\
Intercept, $b$ & 0.27862 & 0.1569 \\
RSD** & 0.4226 & 0.4980 \\
Average recovery $\%$ & 100.39 & 99.11 \\
\hline
\end{tabular}

* $Y=a X+b$, where $X$ is the concentration of salbutamol in $\mu \mathrm{g} / \mathrm{ml}$.

** Average of six determinations. 


\section{Interference}

The extent of interferences by some excipients which often accompanied pharmaceutical preparations were studied by measuring the absorbance of solutions containing $2 \mu \mathrm{g} / \mathrm{ml}$ of salbutamol and various amounts of diverse species in a final volume of $10 \mathrm{ml}$. It was found that the studied excipients do not interfere in the determination of salbutamol in its dosage forms. Fructose and arabic gum showed an interference effect when present in a large excess. An error of $5.0 \%$ in the absorbance readings was considered tolerable. Typical results are given in Table 3.

Table 3: Effect of excipients for assay of salbutamol

Recovery $\%$ of $2 \mu \mathrm{g} / \mathrm{ml}$ of salbutamol per $\mu \mathrm{g}$ excipients added in

\begin{tabular}{|c|c|c|c|c|c|c|}
\hline \multirow{3}{*}{ Excipients } & \multirow{2}{*}{\multicolumn{3}{|c|}{ Method A }} & & & \\
\hline & & & & \multicolumn{3}{|c|}{ Method B } \\
\hline & 100 & 500 & 1000 & 100 & 500 & 1000 \\
\hline Glucose & 99.8 & 101.1 & 100.8 & 102.1 & 102.6 & 104.3 \\
\hline Fructose & 103.2 & 105.2 & 110.5 & 99.7 & 102.5 & 109.1 \\
\hline Starch & 103.0 & 102.4 & 103.4 & 97.0 & 97.4 & 98.3 \\
\hline Magnesium stearate & 102.4 & 100.2 & 104.3 & 99.1 & 100.3 & 100.8 \\
\hline Arabic gum & 102.5 & 104.3 & 110.2 & 100.9 & 103.9 & 109.0 \\
\hline Sodium chloride & 97.9 & 100.4 & 100.8 & 99.8 & 100.0 & 100.5 \\
\hline Sodium bicarbonate & 100.9 & 101.3 & 99.0 & 102.3 & 100.8 & 98.2 \\
\hline
\end{tabular}

\section{Analytical applications}

The proposed methods were successfully applied to determine salbutamol in its pharmaceutical preparations. The obtained results were compared statistically by a Student's $t$-test for accuracy and a variance ratio $F$-test for precision with the official method ${ }^{[10]}$ (depending on potentiometric titration for pure drug using $0.1 \mathrm{M}$ perchloric acid) at the $95 \%$ confidence level with five degrees of freedom, as cited in Table 4. The results showed that the $t$-test and $F$-test were less than the theoretical value $(t=2.667, F=6.39)$, indicating that there was no significant difference between the proposed methods and official method. Moreover, the proposed methods are compared favorably with other reported methods $[13,14]$ as shown in Table 5. 
Table 4. Assay of salbutamol in pharmaceutical preparations using the proposed methods and comparison with the official method.

\begin{tabular}{|c|c|c|c|c|}
\hline \multirow{2}{*}{ Preparation $^{\mathrm{b}}$} & \multirow{2}{*}{$\begin{array}{l}\text { Nominal } \\
\text { Value }\end{array}$} & \multicolumn{3}{|c|}{ Recovery $\% \pm$ RSD $^{\mathrm{a}}$} \\
\hline & & Method A & Method B & Official method $^{\mathrm{c}}$ \\
\hline $\begin{array}{l}\text { Butadin } \\
\text { (tablet) }\end{array}$ & $2 \mathrm{mg} / \mathrm{Tab}$. & $\begin{array}{l}100.89 \pm 0.82 \\
t=1.37 \\
F=2.84\end{array}$ & $\begin{array}{l}102.31 \pm 1.84 \\
t=1.19 \\
F=1.68\end{array}$ & $99.85 \pm 0.85$ \\
\hline $\begin{array}{l}\text { Butadin } \\
\text { (syrup) }\end{array}$ & $2 \mathrm{mg} / 5 \mathrm{ml}$ & $\begin{array}{l}102.65 \pm 1.47 \\
t=1.91 \\
F=1.59\end{array}$ & $\begin{array}{l}103.73 \pm 1.72 \\
t=1.94 \\
F=2.15\end{array}$ & $99.85 \pm 0.85$ \\
\hline
\end{tabular}

Table 5: Comparison of results for the determination of salbutamol by the proposed methods and the reported methods

\begin{tabular}{|c|c|c|c|c|c|}
\hline Reagent used & $\begin{array}{l}\lambda_{\max } \\
(\mathrm{nm})\end{array}$ & $\begin{array}{l}\text { Beer's law limit } \\
(\mu \mathrm{g} / \mathrm{ml})\end{array}$ & $\begin{array}{l}\text { Molar absorptivity } \\
\text { (L.mol-1 } 1 \mathrm{~cm}-1)\end{array}$ & Application & Remarks \\
\hline $\begin{array}{l}\text { Cerium(IV)- } \\
\text { MBTH }^{\mathrm{a}}[15]\end{array}$ & 530 & $0-15$ & $2.4 \times 10^{4}$ & --- & $\begin{array}{ll}\text { Involves } & \text { extraction } \\
\text { and an } & \text { expensive } \\
\text { reagent } & \end{array}$ \\
\hline $\begin{array}{l}\mathrm{BrO}_{3}^{-}-\mathrm{Br}^{-} \\
\text {/methyl } \\
\text { orange [18] }\end{array}$ & 510 & $0.5-5$ & $7.17 \times 10^{4}$ & Tablet & $\begin{array}{l}\text { Involves several reagen } \\
\text { critical conditions }\end{array}$ \\
\hline $\begin{array}{c}\mathrm{F}-\mathrm{C} \text { reagent } \\
{[13]}\end{array}$ & 750 & $1-15$ & --- & Tablet, urine & $\begin{array}{l}\text { Uses on-line solid- } \\
\text { phase } \\
\text { extraction and flow- } \\
\text { injection }\end{array}$ \\
\hline $\begin{array}{l}\text { Fe-1,10- } \\
\text { phenanthrolin } \\
\text { e }\end{array}$ & 510 & $0.15-6$ & $7.858 \times 10^{4}$ & Tablet, syrup & Proposed method A \\
\hline $\begin{array}{l}\text { Fe-2,2'- } \\
\text { bipyridyl }\end{array}$ & 520 & $0.25-8$ & $4.555 \times 10^{4}$ & Tablet, syrup & Proposed method B \\
\hline
\end{tabular}

\section{Conclusion}

The proposed methods are sensitive and reasonably accurate and precise. Method A (used 1,10-phenanthroline) was found to be more sensitive compared to method B (used 2,2'-bipyridyl) for the assay of salbutamol. The coloured complexes are stable for more than $24 \mathrm{~h}$, which makes the methods more practicable. The validity of the proposed methods is well demonstrated by analyzing the dosage form of salbutamol (tablet and syrup). Moreover, the methods are free from interference by common additives and excipients. 


\section{References}

[1] Parfitt K. (Ed.), Martindale. The Complete Drug Reference, 32nd ed.,

Pharmaceutical Press, London, 1999.

[2] Ouyang J., Duan J. L., Baeyens W. R. G. and Delanghe J. R., Talanta, 65,16.(2005).

[3] Colthup P. V., Dallas F. A. A., Saynor D. A., Carey P. F., Skidmore L. F. and Martin L. E., J. Chromatogr. Biomed. Appl. 345, 111-118,(1985).

[4] Argekar A. P. and Powar S. G., J. Planar Chromatography--Modern TLC, 11, 254 257, (1998).

[5] Huclová J., Šatínský D., Sklenárová H. and Karlícek R., Anal. Bioanal. Chem., 376, 448-454,(2003).

[6] Yilmaz N., Ozkan S. A., Urk B.U. and Iryol I.B., Tr. J. of Chemistry, 22, 175 182,(1998).

[7] Issa Y. M., Shoukry A. F. and El-Nashar R. M., J. Pharm. Biomed. Anal. 26, 379-386, (2001).

[8] Yongfu Z. and Fenxi Huaxue, 20, 199-201,(1992), in Chinese.

[9]Dol I. and Knochen M., Talanta, 64, 1233-1236,(2004).

[10] British Pharmacopoeia, 2000, v4.0, CD Room.

[11] United States Pharmacopeia, 26th revision, United States Pharmacopeial Convention, Rockville, 2003, p. 56.

[12] Sadler N.P. and Jacobs H., Talanta, 42,1385-1388,(1995).

[13] Satinsky D., Karlicek R. and Svaboda A., Anal. Chim. Acta, 455,103 -109,(2002).

[14] Basu M. and Pathak B., Indian Drugs, 28, 109-110,(1990).

[15] Geetha N. and Baggi T.R., Microchem. J., 39,137 -144,(1990).

[16] Naidu N.V., Naidu D.V., Rajeshwari C.V. and Naidu P.R., Acta,Chim.Hung., 126,821-824,(1989).

[17] Vishwanth K.K., Rao A.S. and Shivaramakrishnan M.V., Indian Drugs, 26,516518,(1989).

[18] Basavaiah K. and Prameela H.C., Anal. Bioanal. Chem., 376, 879-883, (2003).

[19] Patel R.B., Patel A.S. and Pallavi U., Indian Drugs, 24,298 -302,(1987).

[20] Sanghavi N.M. and Vyas J.T., Indian Drugs, 34,463 - 466,(1998).

[21] Bakry R.S., El-Walily A.F. and Belal S.F., Anal Lett., 28,2503-2519,(1995)

[22] Mohammed G.G., Khalil S.M., Zayed M.A. and Abdel Hamid-El-Shall M.

J Pharm. Biomed. Anal., 28,1127-1137,(2002).

[23] Nagaralli B. S., Seetharamppa J. and Melwanki M. B., J. Pharm. Biomed. Anal., 29, 859-864,(2002).

[24] Amin A. S. and Ragab G. H., Anal. Sci., 19,747-751,(2003).

[25] Singh D. K., Srivastava B. and Sahu A., Anal. Sci., 20,571-573,(2004). 